\title{
OS EFEITOS DO CONTROLE JUDICIAL DE CONSTITUCIONALIDADE NOS ESTADOS UNIDOS, CANADÁ E AMÉRICA LATINA NUMA PERSPECTIVA COMPARADA
}

KEITH S. ROSENN*

\begin{abstract}
Introdução - 1. O Efeito de uma Declaração de Inconstitucionalidade de Lei nos Estados Unidos - 2. Os Efeitos de uma Declaração de Inconstitucionalidade no Canadá - 3. Os Efeitos da Declaração de Inconstitucionalidade no México - 4. Os Efeitos de uma Declaração de Inconstitucionalidade no Chile - 5. Os Efeitos de uma Declaração de Inconstitucionalidade na Argentina - 6. Os Efeitos de uma Declaração de Inconstitucionalidade no Equador - 7. Os Efeitos de uma Declaração de Inconstitucionalidade na Colômbia - 8. Os Efeitos de uma Declaração de Inconstitucionalidade no Brasil - 8.1. Controle Incidental - 8.2. Controle Concentrado - 8.2.1. A Ação Direta de Inconstitucionalidade - 8.2.2. A Ação Declaratória de Constitucionalidade - 8.2.3. O Descumprimento de Preceito Fundamental - 8.2.4. A Ação de Inconstitucionalidade por Omissão - 9. As Vantagens e Desvantagens dos Efeitos Erga Omnes e Inter Partes
\end{abstract}

\section{Introdução}

Em seu trabalho pioneiro, Judicial Review in the Contemporary World ${ }^{1}$, o Professor Mauro Cappelletti, um dos mais ilustres professores da Itália, divide os sistemas de controle judicial de constitucionalidade (Judicial review) em duas categorias básicas: desconcentrado e concentrado. Sistemas desconcentrados ou difusos, cujo arquétipo são os Estados Unidos, conferem o poder de decidir questões constitucionais a todo o Judiciário. Sistemas concentrados, cujos arquétipos são Áustria e Alemanha, restringem o exercício do controle de constitucionalidade a Corte Constitucional especial.

* Tradução e notas de Paulo Gomes Pimentel Júnior.

I Indianapolis: Bobbs-Merrill Company, Inc. 1971.

R. Dir. Adm.,

Rio de Janeiro, 235: 159-185, Jan./Mar. 2004 
Uma segunda diferença básica entre os dois sistemas é o modo como as matérias constitucionais são apresentadas nos tribunais. Nos sistemas concentrados, as matérias constitucionais podem ser apresentadas diretamente ao Tribunal Constitucional em abstrato ad hoc procedimentos que são divorciados das lides ordinárias. Legitimado a instaurar ações diretas de inconstitucionalidade é geralmente um seleto grupo de agentes governamentais ou entidades. Nos sistemas desconcentrados, as partes apresentam as matérias constitucionais aos tribunais no curso de ações ordinárias. As questões constitucionais devem ser decididas num contexto de realis, vivos e concretos casos em vez de disputas abstratas.

Uma terceira diferença básica entre os dois sistemas é o efeito da declaração de inconstitucionalidade. Nos sistemas concentrados, uma decisão declaratória de inconstitucionalidade de lei geralmente tem efeitos erga omnes, invalidando a lei para todos, tal como se tivesse sido ab-rogada pelo Legislativo. Num sistema desconcentrado, uma decisão declarando a inconstitucionalidade de lei tecnicamente apenats tem efeitos inter partes. Nos sistemas desconcentrados fiéis à tradição do common law, entretanto, a doutrina do stare decisis ${ }^{2}$ dá à decisão judicial o efeito de um precedente vinculante. Isto significa que em futuras lides, o próprio tribunal, e todos os outros subjacentes na hierarquia judiciária, devem decidir casos semelhantes da mesma maneira ${ }^{3}$. Por conseguinte, se a mais alta corte no sistema desconcentrado de common law decide que uma lei é inconstitucional em tese, não deve ser aplicada a ninguém. Se, todavia, ela é considerada inconstitucional em relação à determinada categoria de litigantes, deve ser aplicada aos demais distintos. Declarações de inconstitucionalidade nos sistemas concentrados operam ex nunc, tendo apenas efeitos prospectivos $^{4}$. Declarações de inconstitucionalidade nos sistemas difusos operam ex tune, tendo efeitos retroativos até a data da edição da lei inconstitucional.

2 N. do T. "Stare decisis (pronunciase stare diçáicis) é o que sobrou da expressão latina "stare decisis et non quicta movere": ao pé da letra: 'que as coisals permaneçam fïmes e imodificadas. em razão das decisões" (SOARES, Guido Fernando Silva. Common Law: Introdução ao Direito dos EUA. 2 ed., São Paulo: Revista dos Tribunais. 2000, p. 35. nota de rodapé n 3). "Cumprir ou aderir aos casos julgados', é a política de direito angloamericano de decidir uma ciasa do mesmo modo como as culusas anteriores semelhantes foram decididas. É teoria de uniformização de jurisprudência" (MELLO, Maria Chaves de. Dicionário Juridico: Português-Inglês, Inglês-Português. 7 ed., Rio de Janeiro: Elfos, 1998, p. 458).

3 A doutrina do stare decisis não impede que os tribunais rejeitem seus próprios precedentes. se bem que isto é raramente feito. A Suprema Corte dos EUA, entretanto, é menos inclinada a aderir ao stare decisis com respeito às questões constitucionais que em outros assuntos. V. Michacl Gerhardt, The Role of Precedent in Constitucional Decision making and Theory, 60 GEO. WASH. L. REV. 68 (1991); Henry P. Monaghan, Stare Decisis and Constitutional Adjudication, 88 COLUM. L. REV. 723, 740741 (1988).

4 Por exemplo, a constitucionalidade de qualquer lei federal ou estadual pode ser questionada, a qualquer tempo, depois de decretada perante Tribunal Constitucional alemĩo em um processo conhecido como "controle abstrato de normas". Legitimados a inaugurar este processo estão somente o Governo Federal (Bundesregierung), oGoverno Estadual (Land). ou um terço dos 
Como este artigo mostrará, a despeito do uso geral da estrutura analítica do Professor Cappelletti, muitos países das Américas desenvolveram modelos híbridos de controle judicial. Alguns combinam Tribunais Constitucionais especiais com o controle difuso. Outros combinam o sistema difuso com o controle jurisdicional abstrato pela Corte Suprema. Alguns permitem controle jurisdicional preventivo nos quais os tribunais decidem a constitucionalidade de projetos de lei ou vetos. Outros ainda autorizam o Legislativo a sobrepujar ou contradizer declarações judiciais de inconstitucionalidade. Como resultado. os efeitos das declaraçōes de inconstitucionalidade variam consideravelmente de país a país e, em alguns deles, variam com o tipo de procedimento através do qual a matéria constitucional é suscitada. Em alguns, os efeitos das decisões judiciais de constitucionalidade operam apenas inter partes. Em outros, certas decisões judiciais têm efeitos erga ommes, encjuanto outras operam apenas inter partes. Em alguns, as declarações de inconstitucionalidade têm efeitos retroativos, enquanto noutros tais decisões apenas operam prospectivamente. Em uns, uma lei declarada inconstitucional é revogada, enquanto em outros a norma inconstitucional permanece em vigor.

Parte da complexidade é o resultado da mistura única entre as tradições do common e do civil law e dos diversos modelos de controle judicial que se desenvolveram nas Américas. Muitos países da América Latina, particularmente nos últimos quinze anos, aumentaram vastamente os poderes de seus tribunais de declarar normas inconstitucionais combinando os modelos concentrados da Europa com o modelo americano de controle difuso. Como resultado, o papel dos tribunais em interpretar a Constituição e proteger direitos e liberdades constitucionais aumentou substancialmente. Há, entretanto, sérias preocupações em que o desenvolvimento de modelos híbridos possa resultar em forçar mal-preparados juízes de civil law a executar as altas funções políticas do controle judicial sem a rede de segurança da variedade de técnicas que os juizes da common law desenvolveram para evitar decidir matérias constitucionais que provavelmente os envolveria em sérios conflitos com os outros órgãos do Estado. Em uma região com uma débil tradição de estado de direito e uma forte tradição de dominação do Executivo ${ }^{5}$, os efeitos de longo prazo sobre a independência judicial podem ser desastrosos.

membros do Parlamento Federal (Bundestag). Se o Tribunal declara que a lei inteira ou um dispositivo inseparável é inconstitucional, o efeito da decisão é de nulificar a lei. A decisão será publicada no Diário Oficial e tem força de lei. O Tribunal, entretanto, pode invalidar apenas parte da lei, ou simplesmente declarar a lei incompatível com a Lei Fundamental. Porém, o Legislativo tem a opção de revogar a lei, se não quiser que ela continue em vigor sem a parte inválida, ou emendar a lei para torná-la compatível com a Lei Fundamental. A última opção é normalmente restrita a casos nos quais a lei ilicitamente exclui de un grupo vantagens conferidas al outros. Sabine Michałowski \& Lorna Woods, German Constitutional Law: The Protection of Civil Liberties 43-44 (Hants, England/Brookfield, Vermont: Dartmouth/Ashgate 1999).

5 Keith S. Rosenn, The Success of Constitutionalism in the United States and lts Failure in Latin America: An Explanation, 22 U. MIAMI INTER-AM. L. REV. 1 (1990). 


\section{O Efeito de uma Declaração de Inconstitucionalidade de Lei nos Estados}

Unidos

O modelo clássico de controle judicial difuso é o dos Estados Unidos. Qualquer tribunal federal ou estadual tem o poder de decidir sobre a constitucionalidade de qualquer lei ou decreto federal, estadual ou municipal. Enquanto a Suprema Corte americana é o último árbitro do significado da Constituição e do Direito Federal, os Supremos Tribunais dos Estados são os últimos árbitros do significado das Constituições e Leis estaduais.

No modelo dos EUA, o controle de constitucionalidade é incidental à função dos tribunais no decidir casos concretos. De acordo com o artigo III da Constituição, os tribunais federais podem decidir apenas casos reais e concretos entre partes adversas. Eles não podem declarar uma lei ou outra norma inconstitucional em um processo abstrato. Além disso, a Suprema Corte recusa-se a conferir legitimidade a pessoas para ajuizar reclamações de interesses gerais, insistindo que apenas pessoas com uma "lesão de fato" (injury in fact) podem ter legitimidade para promover ação nos tribunais federais. Determinados estados, entretanto, permitem pareceres consultivos nos quais o Judiciário pode dar conselho a outro órgão governamental sobre o significado de um dispositivo constitucional ou legal ${ }^{6}$. Tais pareceres não são sentenças e não são precedentes vinculantes em futuros processos?

Qual o efeito de uma declaração pelo mais alto tribunal na jurisdição de que uma lei é inconstitucional? É a lei uma nulidade? É ela apagada dos códigos? Ou ela continua a subsistir em efeitos? O que acontece se apenas parte da lei é declarada inconstitucional? O que acontece se a decisão judicial declarando uma lei inconstitucional é subsequientemente revogada? A lei automaticamente ressuscita ou deve ser novamente promulgada?

Desde o caso original de Marbury v. Madison em 1803, os tribunais dos EUA têm assumido que uma lei inconstitucional é nula $a b$ initio $^{8}$. Nas palavras do Justice $e^{y}$ Field: “Um ato inconstitucional não é uma lei: não confere direitos; não impõe

6 Colorado, Flórida, Maine, Massachusetts. Michigan. New Hampshire, Rhode Island, e Dakota do Sul têm dispositivos constitucionais autorizando suas cortes supremas a expedir pareceres consultivos. Alabama, Delawatre, e Oklahoma têm leis autorizando suas cortes a emitir pareceres consultivos. Harl and Wechsler's The Federal Courts and the Federal System 84 (Richard H. Fallon. Daniel J. Meltzer \& David L. Shapiro eds.. 5th ed., Westbury, N.Y.: Foundation Press, 2003).

7 William A. Fletcher, The "Case or Controversy" Requirement in State Law Adjudication of Federal Questions. 78 CALIF. L REV. 263, 285 (1990). Uma vez que as cortes estaduais não estão limitadas pelo Artigo III da Constituição Federal, também existem uma categoria de casos até litigados em cortes estaduais que podem ser tidos como "pareceres consultivos" pois eles não se adequam aos padrões de justiciabilidade federais, mas que constituem precedentes vinculantes sob a lei estatal. Id.

8 Oliver P. Field, The Effect of an Unconstitutional Statute 1-4 (Univ. of Minn. Press: Minneapolís 1935).

9 N. do T. Nos Estados Unidos, os Juízes da Corte Suprema são chamados, individualmente, de "Justice". 
obrigações; não proporciona proteção; não cria funções; é, na contemplação legal, tão inoperante como se nunca tivesse sido aprovado" ${ }^{10}$. Desde então, as decisões de constitucionalidade dos tribunais norte-americanos têm sido inteiramente retroativas, aplicando-se ex tunc a todos os casos não decididos. Em 1965, entretanto, no processo revolucionalizante do procedimento criminal estatal fazendo a maior parte da Declaração de Direitos e Garantias (Bill of Rights) inteiramente aplicável aos estados. a Suprema Corte assentou em Linkletter $v$. Walker que determinadas de suas decisões inovadoras não necessitavam ser aplicadas retrospectivamente às condenações criminais estaduais que tivessem sido firmadas antes delas ${ }^{11}$. No ano seguinte, a Suprema Corte assegurou o poder de fazer suas novas regras em processo criminal não-retroativas, até mesmo para casos pendentes de controle direto. De acordo com a Corte, uma decisão constitucional teria efeitos retroativos ou prospectivos, dependendo de três critérios: (1) o objetivo da nova regra, (2) a extensão da confiança pela polícia sobre decisões anteriores, e (3) o efeito de retroatividade na Administração da Justiça' ${ }^{12}$. Esta norma, que foi difícil, de justificar em teoria, recebeu severas críticas, tanto de comentaristas acadêmicos como do Justice Harlan, que escreveu várias discordâncias irrefutáveis, argüindo que a fidelidade ao precedente e o dever de evitar a aparência de legislação judicial exigia que as decisões constitucionais aplicassem-se retrospectivamente a todos os casos de recursos diretos. Em 1987, a Corte Suprema revogou Linkletter $v$. Walker e resolveu uma vez mais fazer suas decisões totalmente retroativas para todos os casos criminais pendentes de controle direto. Esta decisão baseou-se em duas normas básicas de julgamento constitucional: (1) a natureza do controle judicial não permite a um tribunal ocupar a prerrogativa legislativa de fazer regras de direito retroativas ou prospectivas ao seu arbítrio, e (2) "a aplicação seletiva das novas regras viola o princípio de tratar partes semelhantes da mesma forma" ${ }^{13}$. Não até 1993 a Suprema Corte resolveu que suas decisões constitucionais em casos civis devem também ser totalmente retroativas ${ }^{14}$.

Tecnicamente, as decisões dos tribunais americanos concernentes à constitucionalidade têm apenas efeitos inter partes $A$ decisão afeta apenas às partes em litígio, para quem a lei inconstitucional não deve ser aplicada' ${ }^{15}$. A decisão judicial não ab-roga ou anula a lei, que permanece em vigor e teoricamente pode ser novamente aplicada a quaisquer outros. A doutrina do stare decisis, no entanto, faz com que as decisões judiciais, especialmente aquelas da Suprema Corte, vinculem erga omnes.

10 Norton v. Shelby Courity, 118 U.S. 425, 442 (1886). Esta afirmação nem sempre é verdade, visto que há circunstâncias nas quais leis inconstitucionais têm efeitos juridicos para determinados propósitos, tal como a res judicata.

11 Linkletter v. Walker, 381 U.S. 618 (1965).

12 Johnson v. New Jersey, 384 U.S. 719 (1966); Stovall v. Demmo, 388 U.S. 293 (1967).

13 Griffith v. Kentucky, 479 U.S. 314, 323 (1987).

14 Harper v. Virginia Department of Taxation, 509 U.S. 86 (1993). V. Laurence H. Tribe, American Constitutional Law 218-226, vol. 1, (New York: Foundation Press 2000).

15 Pelo uso corrente de ações de classe (class actions) em lides constitucionais, o número de pessoas que são parte pode ser muito extenso. V. Jack Greenberg, Civil Rights Class Actions: Procedural Means of Obtaining Substance, 39 ARIZ. L. REV. 575 (1997). 
Se a Suprema Corte dos Estados Unidos declara uma lei inconstitucional, ela não é revogada. Não obstante. qualquer funcionário que continue a impor a lei corre um risco substancial. Tanto funcionários federais como estaduais coatores (mas não juízes) podem se sujeitar a ações civis por danos pela violação de direitos civis de pessoas contra as quais eles continuam a impor a lei. Se a má fé puder ser provada, tais funcionários podem também ser obrigados a pagar honorários advocatícios e até indenização punitiva ${ }^{16}$. Qualquer um ameaçado pela imposição de uma lei inconstitucional pode requerer uma medida judicial declaratória o injuntiva. ${ }^{17}$ Funcionários que ignoram as injunçōes judiciais podem ir parar na cadeia por desacatoto ${ }^{1 s}$.

Semelhantemente, a declaração da Suprema Corte de que a lei questionada é constitucional normalmente tem efeitos erga omnes por causa da doutrina do stare decisis. Apesar disso, nada impede que alguém adversamente atingido pelei lei que foi declarada constitucional reinvoque a matéria em tempo posterior, particularmente se decisões posteriores tiverem minado o precedente. É claro, o Congresso permanece livre para revogar a qualquer momento uma lei que entenda inconstitucional até mesmo se a Suprema Corte a tiver julgado constitucional, e o Presidente está livre para vetar qualquer reedição de lei com fundamentos constitucionais. Por exemplo. em $M c C u l l o c h$ v. Maryland ${ }^{14}$, uma unânime Suprema Corte sustentou que uma lei federal instituindo o Banco dos Estados Unidos era inconstitucional. Ainda assim, a Corte enviou uma cópia de sua decisão ao Presidente Andrew Jackson, isto não o impediu de vetar um projeto de lei para renovar o Banco dos Estados Unidos sob o

16 Daniel A. Farber, The Supreme Court and the Rule of Law: Cooper 1. Aaron Revisited. 1982 UNIV. ILL. L. REV. 387, 405-406.

17 N. do T. O termo injunção foi vernaculizado do injuction inglês. Sua definição, ná síntese de Maria Chaves de Mello, é a seguinte: "Remédio jurídico originário da juridição de Equiidade. hoje também aplicado pela justiça comum norte-americana. en lugar do MANDAMLS. (...), que consiste em um mandado judicial proibindo alguém de praticar. ou ordenando que ceesse de praticar. ato ou ação lesivo de direito líquido e certo; corresponde. aproximadamente, ao mandado de segurança do nosso direito, com a diferença de que se aplica tanto à autoridade pública coatora como ao particular" (Dicionário Jurídicu: Pornuguês-Inglês, Inglês-Porluguês, cit., p. 351 ).

$18 \mathrm{~N}$. do T. No texto original, em inglês, autor utilizou o termo contempr, instituto do common law' com aplicação também, em bem menor medida (ainda), no Braıill. A Prof". Ada Pelegrini Grinover, em estudo subre o tema, assim o definiu:

"Atualmente, todos os atos tendentes at obstruir o cumprimento das funçōes de um juízo, envolvendo uma afrontat. podem constituir desacato. Inclui-se no conceito atuall o abuso do processo.

Assim, na definição de Swayze contempt of court é a pritica de qualquer ato que tenda a ofender um tribunal na administração da justiça ou a diminuir sua autoridade ou dignidade. incluindo a desobediênciai a uma urdem.

Com base nessa ampla estera conceitual, o contempt hoje se divide em criminal c civil. O criminal destina-se à punição pela conduta atentatória praticada. O civil destina-se ao cumprimento da decisão judicial, usando para tanto meios coercitivos. Uma conduta desrespeitosa pode ser passível, ao mesmo tempo, de contempt civil e criminal, seja no processo civil, seja no processo penal" (GRINOVER, Ada Pellegrini. Estudos, Capítulo 6: "Abuso do Processo e Resistência ìs Ordens Judiciairias: O Contempt of Court'. Em: A Marcha do Processo. Rio de Janeiro: Forense Universitúria. 2000, p. 65).

1917 U.S. (4 Wheat.) 316 (1819). 
fundamento de que a lei proposta era inconstitucional 20 . Uma vez que o (Congresso careceu de votos para derrubar o veto, nenhuma lei existiu para ser declarada constitucional por qualquer tribunal.

O que acontece se a Suprema Corte dos EUA revoga uma decisão sustentando que a lei é inconstitucional? Enquanto a matéria não tiver sido explicitamente conferida pela Suprema Corte. o entendimento dominante dos tribunais e da doutrina sobre o assunto é que se um caso de declaração de inconstitucionalidade é subseqüentemente anulado. a lei é automaticamente ressuscitada e considerada em vigor descle a data em que foi editada ${ }^{21}$.

As decisões dos tribunais algumas vezes invalidam apenas certas partes de uma lei. A decisão deve deixar em vigor aquelas seções que são constitucionais. desde que possam existir separadamente distinguiveis das partes inconstitucionais. Se preceitos podem existir separadamente é finalmente uma questão de saber se o resto da lei é funcionalmente independente e se o Legislativo teria pretendido manter a lei sem as partes declaradas inconstitucionais. Ocasionalmente. os tribunats empregam uma interpretação restritiva sob uma le para salvá-la de dúvidas constitucionais. Esta opção é viável para os tribunais federais apenas para leis federais; para os últimos árbitros do significado das leis estaduais são os tribunais estaduais 22 .

Uma declaração de inconstitucionalidade pela Suprema Corte freqüentemente tem o efeito de invalidar não apenas a lei questionada, mas também todas as outras leis semelhantes, indepentendemente de terem estado perante a Corte. Por exemplo, no famoso caso de Roe v. Wade e o seu companheiro de Doe v. Bolton ${ }^{23}$. a Suprema Corte declarou inconstitucionais leis do Texals e da Geórgia tornando um crime as mulheres praticarem aborto. Construída a partir de uma série de casos anteriores, a Corte encontrou na cláusula do devido processo (duc process clatuse) da Emenda XIV um direito à privacidade que foi suficientemente amplo para suportar a escolha feminina de dar à luz uma criança. Tecnicamente, a decisão da Suprema Corte declarou inconstitucionais apenas as leis de aborto de dois estados. Uma vez que não havia qualquer meio legítimo para distinguir as leis de outros estados criminalizando o aborto das leis do Texas e da Geórgia, a decisão da Corte em Roe v. Wade e Doe v. Bolton realmente invalidou as leis de aborto de todos exceto os quatro

20 Hart and Wechsler's The Federal Courts and the Federal System 89 (Richard H. Fallon, Danicl J. Meltzer \& David L. Shapiro eds., 4th ed.. Westbury. N.Y.: Foundation Press (996).

21 Earl T. Carford. The Legislative Status of an Linconstiturional Statute. 49 MICH. L. REV. 645. 651 (1951): William M. Treanur \& Gene B. Sperling, Prospective Overruling and the Revival of "Unconstiutional" Leis. 93 COLUM. L. REV. 1902, 1908-1917 (1993) (mas afirmando que determinadas leis deveriam ser revigoradas quando uma decisão declarando-as inconstitucional for rejeitada).

22 Murdock v. City of Memphis, 87 U.S. (20 Wall.) 590). 22 L. Ed. 429 (1875). Semelhantemente. os últimos árbitros se uma lei estadual viola a constituiçio estadual são als cortes estaduais. A Suprema Corte dos EUA não revisará uma decisão de uma corte estadual, mesmo se houver uma importante questão constitucional ou legal, se a decisão estadual descança sob um independente e adequado fundamento exposto.

23410 U.S. 113 (1973): 410 U.S. 179 (1973). 
estados cujas leis permitiam o aborto a pedido. Semelhantemente, a decisão da Suprema Corte em Immigration and Naturalization Service v. Chadha ${ }^{24}$, que declarou uma seção da Lei de Imigração e Nacionalidade inconstitucional porque continha um veto legislativo, teve o efeito de invalidar 295 outros vetos legislativos contidos em 196 leis diferentes.

Não obstante, é un equívoco supor, mesmo nos Estados Unidos, que tem longamente gozado uma reputação de alto respeito pelo estado de direito, que os acórdãos da Suprema Corte são universalmente respeitados. O prestígio dos tribunais americanos é tão grande que suas decisões são normalmente obedecidas como um fato natural. Não obstante, as decisões da Suprema Corte proibitórias de pregadores e leituras bíblicas em escolas públicas são freqüentemente menosprezadas no denominado "Cinturão Bíblico" (Bible Belt) dos Estados Unidos ${ }^{25}$. Além disso, quatro decisões da Suprema Corte foram revogadas por emendas constitucionais ${ }^{26}$, e numerosas tentativas frustradas de reformar a Constituição foram feitas em respostà às decisões controvertidas. Enquanto os esforços do Congresso em revogar decisões constitucionais da Suprema Corte por lei são geralmente frustrados, uma declaração dela de que uma legislação estadual viola a Cláusula de Comércio (Commerce Clause) em seu estado latente pode ser derrubada por legislação subsequüente do Congresso ${ }^{27}$.

\section{Os Efeitos de uma Declaração de Inconstitucionalidade no Canadá}

Como os Estados Unidos, o Canadá tem tanto um sistema difuso de controle judicial como a doutrina do stare decisis. Também, como os tribunais americanos, os canadenses às vezes restritivamente interpretam uma lei para preservar sua constitucionalidade, uma prática conhecida como "leitura para baixo" (reculing down). e algumas vezes invalidam apenas parte de uma lei quando realmente separável. Ao contrário dos Estados Unidos, a Suprema Corte do Canadá é o último árbitro do

24 Immigration and Naturalization Service v. Chadha, 462 U.S. 919 (1983).

25 Robert H. Birkby, The Supreme Court and the Bible Belt: Tennessee Reaction to the "Schempp" Decision, in Prayer in Public Schools and the Constiturion. 1961-1992, 440 (Robert: Sikorksi ed.. Garland Pub.: New York \& London, 1993); H. Frank Way, Jr., Survey Research on Judicial Decisions The Prayer and Bible Reading Cases, ibid., 189.

26 Chisolm v. Georgia, 2 U.S. (2 Dall.) 419 (1793) foi revogado pela XI Emendil. Dred Scott v. Sanford. 60 U.S. (19 How.) 393 (1856), que ajudou a precipitar a Guerra Civil. toi revogada pela XIV Emenda. Pollock v. Farmers' Loan \& Trust Co.. 157 U.S. 429 (1895) foi revogada pela XVI Emenda. Oregon v. Mitchell, 400 U. S. 112 (1970) foi revogada pela Emenda XXVI.

27 Compare City of Boerne v. Flores, 521 U.S. 507 (1997) com Leisy v. Hardin, 135 U.S. 100 (1890) (sustentando que um estado não pode proibir a venda e importação de licor no pacote original) e Inre Rahrer, 140 U.S. 545 (1891) (sustentando-se uma condenação estatal de venda de licor no pacote original porque o Congresso, por reedição da Lei Wilson, permitiu tais legislações estaduais, desse modo "reformando" Leisy v. Hardin). 
significado tanto das leis federais quanto provinciais ${ }^{2 x}$. Mas a forma em que as matérias constitucionais são suscitadas e as conseqüências de uma determinação judicial de constitucionalidade podem ser um pouco diversas do controle dos Estados Unidos.

Por exemplo, a Lei da Suprema Corte e correspondentes legislações provinciais habilitam o Governador (Governor in Council) ou o Vice-Governador (Lieutenant Governor in Council) a submeter questões constitucionais respectivamente à Suprema Corte ou aos tribunais provinciais superiores. Os tribunais estão incumbidos de apreciar e decidir as questões, mesmo se não houver real controvérsia entre partes interessadas ${ }^{29}$. Os Advogados-Gerais (Attorney's General) estão autorizados a intervir em questões de direito, e outras partes interessadas podem ter permissão para intervir. Além disso, ao contrário dos tribunais americanos, os canadenses têm relaxado em fixar requisitos para suscitar questões constitucionais "quase a ponto de desaparecimento" ${ }^{30}$. Consequientemente, os tribunais canadenses habitualmente decidem reclamações gerais de cidadãos, decidindo matérias constitucionais em processos que são essencialmente abstratos.

Como nos Estados Unidos, o Canadá historicamente considera uma lei declarada inconstitucional como nula e sem efeitos. O Artigo 52(1) do Ato Constitucional de $1982 \mathrm{fez}$ este princípio explícito ao prever que "qualquer lei que contrarie os preceitos da Constituição é, na medida de sua incongruência, inválida e inefícaz". A despeito deste preceito, determinadas leis devem permanecer em vigor no Canadá mesmo após terem sido declaradas inconstitucionais. Anteriormente a 1982, o controle jurisdicional no Canadá não envolvia queixas de violações aos direitos dos indivíduos. Em 1982, o Canadá adotou a Carta de Direitos e Liberdades, que expôs pela primeira vez uma lista constitucional de direitos e liberdades. O artigo $24(1)$ dessa Carta garante a qualquer um cujos direitos tiverem sido infringidos o direito de buscar a tutela judicial de um tribunal competente. Por outro lado, a Seção 33 permite aos Legislativos federal e provinciais sobrepujar decisões judiciais de inconstitucionalidade por expressamente declarar que uma lei operará nāo obstante seus conflitos com certos direitos constitucionais fundamentais (e.g.. livre manifestação de pensamento mas não o direito de votar). A lei inconstitucional pode ser mantida em vigor por um período de cinco anos, renovável por outros cinco.

Nove semanas depois de publicada a Carta, o Quebec decretou um cancelamento geral, revogando toda legislação provincial em vigor e reeditando-a com um preceito sobrepujarite ${ }^{31}$. Embora tenha sustentado a constitucionalidade desta tática, a Suprema Corte canadense também declarou a lei de Quebec proibitiva de anúncios em

28 Martha A. Field, The Differing Federalisms of Camada and the United States, 55 L. \& CONT. PROB. 107, 113 (1992).

29 Bary L. Strayer, The Canadian Constitution and the Courts: The Function and Scope of Judicial Review 170 (Toronto \& Vancouver: Butterworths, 3d ed. 1988).

30 Id. At 153.

31 Mark Tushnet, Policy Distortion and Democratic Debilitation: Comparative llumination of the Countermajoritarian Difficulty, 94 MICH. L. REV. 245, 287 (1995). 
qualquer língua outra que não o francês inconstitucional ${ }^{32}$. Já que o quiinquiênio expiraria dentro de dois meses da decisão da Suprema Corte, o Quebec teve de utilizar uma Seção adicional com 33 cancelamentos para manter a lei inconstitucional em vigor. Esta ação produziu uma signiticativa reação violenta nos falantes de língua inglesa do Canadá, fazendo o preceito sobrepujante politicamente intragável em todo o Canadá à exceção de Quebec ${ }^{33}$.

Diferentemente dos Estados Unidos. os tribunais canadenses nunca desenvolveram uma doutrina de efeitos prospectivos de inconstitucionalidade. Uma decisão judicial de que a lei é inconstitucional é retroativa no sentido de que envolve nulificação da lei desde o princípio ${ }^{34}$.

\section{Os Efeitos da Decharaçäo de Inconstitacionalidade no México}

O México, como os Estados Unidos, Canadá e Argentina, é um sistema federal. Diferentemente daqueles países, o México tem um sistema hibrido de controle judicial. O sistema é quase-desconcentrado em que qualquer tribunal tederal pode declarar tanto uma lei federal como uma lei estadual inconstitucional, mas nenhum tribunal estadual deve declarar leis inconstitucionais ${ }^{35}$. Diversamente dos Estados Unidos ou Argentina. o árbitro fïnal do significado da lei estadual é a Suprema Corte Federal mexicana ou os Tribunais Federais Colegiados e Unitários de Circuito. O principal expediente processual para o exercício do controle judicial é o amparo, que permite aos tribunais federais declarar leis ou outras normas inconstitucionais como aplicadas ou apresentadas. Até mesmo se as leis são declaradas inconstitucionais em tese, a decisão tem apenas efeitos inter partes ${ }^{36}$. Isso há muito tem sido considerado necessário para evitar conflitos prejudiciais entre os tribunais e as autoridades políticals.

Em 1950-51, o artigo 107 (XIII) da Constituç̧̃o foi reformado para permitir à Lei de Amparo habilitar decisôes dos tribunais federais a constituírem precedentes vinculantes ${ }^{37}$. Embora essa linguagem tenha sido suprimida na Reforma de 1968, a Lei de Amparo continua a fazer, após cinco decisões consecutivas de amparo, uma jurisprudência (tesis de jurisprudencia). vinculante para os tribunais que a deliberaram e para aqueles inferiores na hierarquia. A jurisprudencia deve ser aprovada por

32 Ford v. (Quebec (Atturney General). [1988] 2 S.C.R. 712.

33 Peter H. Russell. The Gronth of Canadian Jadicial Revien and the Commonneath and American Experiences, in Comparative Jadicial Re'ien and Pablic Policy 29.36-37 (Donald W. Jackson \& C. Neal Tatte eds.. Westport. Ct. \& London: Greenwood Press. 1992).

34 Peter W. Hogg. Constitucional Law of Canada 345 (Toronto: Carswell 2d ed. 1985).

35 Const. do Mex., ants. 103(1) e 107(VIII).

36 O artigo 107 (II) da Constituição mexicana corporifica uma celcbrada "fórmula Otero", que prevê que o julgamento em açôes de amparo "apenas afeturá indivíduos particulares, limitando-se a ampará-los e protegê-los no caso especial sobre o qual werse a queixa, sem fazer una declaração geral a respeito da lei ou ato cule a motivar".

37 Richard D. Baker, Judicial Review in Mexico 251 (Austin, London: Univ. Tex. Press 1971). 
ao menos oito Ministros de Suprema Corte Federal em pleno, por pelo menos quatro Ministros de suas Turmas (Sclas), ou unanimemente pelos Tribunatis Colegiados de Circuito (Tribunales Colegiados de Circuito) ${ }^{38}$. A jurisprudência, entretanto, não vincula os outros Poderes do Estado.

O tipo de precedente estabelecido pela jurisprudência mexicana é um pouco diferente dos estabelecidos pelos tribunais americanos e canadenses. Uma tesis de jurisprudencia é usualmente apenas uma sentença duradoura e livremente flutuante, inteiramente sem relação com os fatos dos cinco casos em que foi baseada. Diferentemente das decisões americanas ou canadenses, a jurisprudência mexicana não cria novas normas. Mais exattamente ela consiste quase invariavelmente em interpretações técnicas ou clarificações de preceitos constitucionais e legais. Uma Reforma Constitucional, promulgada pelo Presidente Ernesto Zedillo em 31 de dezembro de 1994, fez dramáticas mudanças na Suprema Corte mexicana. em sula competência. e nos efeitos de suas decisões ". Um de seus maiores aspectos controversos foi forçar todos os vinte e um Ministros ativos da Suprema Corte al aposentarem-se precocemente. A medida reduziu o número de Ministros para once. Também. mudou o prazo de seus mandatos de vitalícios a não-renováveis quinze anos. Além disso, a medida mudou o processo de seleção de indicação presidencial para eleição por dois terços do Senado de uma chapa proposta pelo Presidente da República. O número de Turmas foi reduzido de quatro para duats.

Emendas ao artigo 105 da Constituiçĩo agora garantem à Suprema Corte mexicana o poder de resolver litígios federativos com efeitos erga omnes em cinco tipos de ações ${ }^{\text {to }}$. Estas ações devem ser apresentadas diretamente perante a Suprema

38 Ley de Amparo, arts. 192-93, consoante a cmenda de 09 de junho de 2000. Resoluções que clarifiquem contradições nas decisōes judiciais reiteradas das Câmaras e dos Tribunais Colegiados de Circuito também constituem jurisprudéncia. $/$ l., art. 192. Por conseguinte, a jurisprudencia estabelecida através de cinco decisões consecutivals do pleno da Suprema Corte é vinculante para a própria Corte, suas Cámaras. para os Tribunais Colegiados de Circuito. us juizes distritais. Tribunais Militares, Tribunais Administrativos e Trabalhistas. e Tribunais estaduais. A aptidádo dos tribunais de criar jurisprudência está implicitamente autorizada pelo artigo 107 (IX) e (XIII) da Constituição mexicana. A jurisprudência cessia de ser vinculante se uma decisão contrárial é tomada por oito membros da Suprema Conte en banc, quatro membros de uma Câmara. ou de um unânime Tribunal Colegiado de Circuito. Id., art. 194. consoante al enenda de 09 de junho de 2000.

39 Para uma análise de sua reforma, v. Jorge A. Vargas. The Rebirth of the Supreme Court of Justice of Mexico: A Commentary and Appraisal of President Zedillo's Judicial Reform of 1995, 11 AM. U. J. INT'L \& POL'Y 295 (1996); Héctor Fix-Fierro, Judicial Reform and the Supreme Court of Mevico: The Trajectory of Three Years. 6 U.S.-MEX. L. J. 1 (1998); Note. Liberalismo contra Democracia: Recent Judicial Reform in Mexico, 108 HARV. L. REV. 1919 (1995).

40 36. Os cinco tipos de citsos (excluindo matéritis elcitorais) são:

1. Questões suscitadas pelo Governo Federal contra normas estaduais ou municipars.

2. Questōes suscitadas pelos estados contra disposiçōes gerais de seus municípios.

3. Controvérsias entre o Poder Exccutivo Federal e o Congresso ou qualquer de slias Caisits; ou entre uma Comissão Permanente e órgãos federais ou os do Distrito Federal.

4. Controvérsias entre os poderes de um nesmo estado sobre al constitucionalidade de seus atos ou disposiçōes gerais. 
Corte dentro de trinta dias após a lei questionada ter sido editada. Os processos são abstratos, não exigindo qualquer queixoso que tenha realmente sofrido algum prejuízo. Decisões declarando una lei inconstitucional têm efeitos gerais apenas se pelo menos oito Ministros da Suprema Corte concordarem.

Ações diretas de inconstitucionalidade questionando leis federais ou aquelas do Distrito Federal somente podem ser apresentadas pelo Procurador-Geral da República ou pelo menos um terço dos membros das duas casas do Congresso Nacional. A constitucionalidade de tratados internacionais pode ser questionada por pelo menos um terço dos membros do Senado ou pelo Procurador-Geral. A constitucionalidade das leis de um estado ou do Distrito Federal pode ser questionada apenas por pelo menos um terço dos membros de cada casa do Legislativo estadual que a editou ou um terço da Assembléia Geral do Distrito Federal. A declaração de inconstitucionalidade nesses processos abstratos não tem efeito retroativo, exceto em questōes criminais $^{41}$.

\section{Os Efeitos de uma Declaração de Inconstitucionalidade no Chile}

O Chile tem um curioso sistema híbrido de controle judicial, combinando um sistema desconcentrado com uma variação do sistema francês de controle preventivo e concentrado. A Constituição de 1980 restabeleceu o Tribunal Constitucional, que tem o poder de determinar em abstrato a constitucionalidade de projetos legislativos, emendas constitucionais, e tratados anteriormente à promulgação. O Tribunal Constitucional, como o Conselho Constitucional francês, é uma instituição autônoma que não é parte do Judiciário ${ }^{42}$.

As mais importantes três categorias de competência do Tribunal Constitucional são: (1) o dever de determinar a constitucionalidade de todas as leis orgânicas ou leis de interpretação da Constituição anteriormente à submissão ao Presidente para sua sanção ou veto; (2) a pedido do Presidente da República, do Senado ou da Câmara de Deputados, ou um quarto de seus membros ativos. o Tribunal pode determinar a constitucionalidade de um projeto de lei ordinária, de uma proposta de emenda constitucional, ou qualçuer tratado submetido para aprovação do (Congresso; e (3)

5. Controvérsias entre os órgãos do Distrito Federal sobre a constitucionalidade de seus atos ou disposiçōes gerais.

41 Aplicações retroativals apenas podem beneficiar e não prejudicar o acusaldo. V. Const. do Mex., art, 14; José Ramón Cossio D.. Comentario: Artículo 105, in Instituto de Investigaciones Juridicas (UNAM), 2 Constitución Política de los Estados Unidos Mexicanos Comentada 1067 (Porrúa: Mexico City, 1999).

42 O Tribunal Constitucional tem sete membros. três dos quais devem ser escolhidos pela Suprema Corte dentre seus próprios membros. Os outros quatro membros compreendem um advogado indicado pelo Presidente da República, dois advogados indicados pelo Conselho de Segurança Nacional, e um advogado designado pelo Senado. Os membros do Tribunal exercem suas funçōes em um mandato de oito anos, com parte de seus pares sendo selecionados a cada quatro anos (Const. de 1980, art. 81). 
o Tribunal pode determinar a constitucionalidade de um decreto com força de lei, a pedido do Presidente se o Controlador-Geral (Controlador General) tiver rejeitado como inconstitucional um decreto presidencial com força de lei, ou a pedido de cada câmara do Congresso ou uma subsérie de um quarto de seus membros ativos se o questionamento da constitucionalidade de um decreto com força de lei tiver sido rejeitado pelo Controlador Geral. Membros do Congresso podem também provocar o Tribunal se o Presidente não promulgar uma lei ou incorretamente o fizer, ou suscitar uma convocação presidencial a um pebliscito (art. 82).

Decisões do Tribunal Constitucional são finais, irrecorríveis e vinculantes erga omnes. Se o Tribunal decidir que um projeto de lei ou tratado é inconstitucional não deve ser promulgado. Por outro lado. se o Tribunal determina que a lei proposta ou o tratado é constitucional, não se os podem mais invalidar subsequientemente com os mesmos fundamentos que foram expendidos em favor da constitucionalidade na decisão do Tribunal (art. 83).

O Chile também tem uma outra forma concentrada de controle judicial chamada o recurso de inaplicabilidade. A Suprema Corte tem o poder exclusivo, tanto a pedido da parte ou ex officio, de declarar inaplicável sob fundamentos constitucionais qualquer preceito contido em qualquer lei, decreto com força de lei, ou tratado (art. 80). Este poder é limitado a casos concretos ou outras questões ou processos cuja resolução exija uma determinação de constitucionalidade. Diversamente do Tribunal Constitucional, a Suprema Corte carece de poder para declarar uma lei inconstitucional com efeitos erga omnes. A determinação da Suprema Corte de que uma lei é "inaplicável" por causa de inconstitucionalidade é vinculante apenas para as partes. A lei violadora permanece em vigor e pode ser aplicada a outras pessoas ${ }^{43}$.

$\mathrm{O}$ Chile tem ações de proteção e amparo (habeas corpus) que podem ser ajuizadas em juízos singulares para proteger direitos constitucionais e infraconstitucionais, mas estas ações não podem ser utilizadas para determinar a constitucionalidade da legislação ${ }^{44}$. Entretanto, a doutrina reciente toma a posição que 0 artigo 6 da Constituição confere a todo juiz a competencia e o dever de preterir uma norma que se considera inconstitucional ${ }^{45}$.

\section{Os Efeitos de uma Declaração de Inconstitucionalidade na Argentina}

De 1887 a 1994, a Suprema Corte argentina, sem expressa autorização constitucional, desenvolveu um sistema desconcentrado de controle judicial no qual todos

43 Edith Z. Friedler, Judicial Revien in Chile. 7 SW. J. L. \& TRADE AM. $321-347$ (2000). Segado coords., Madrid: Dykinson, S.L. 1997).

44 V. Humberto Nogueira Alcalá, La Jurisdicción Constituticional en Chile, in La Jurisdicción Constitucional en Iberoamerica 533, 562-570 (Domingo Garcia Belaunde \& Francisco Fernández). Segado coords., Madrid: Dykinson, S.L. 1997).

45 V. Luz Bulnes Aldunate, La fuerza normativa de la Constitución. REV. CHILENA DE DERECHO 131-136 (Número especial 1998); Miguel Angel Fernández Gouzález. La, fuerza normaliva de la Constitución, 63 REV. DERECHO PÚBLICO 77. 95-102 (2001). 
os niveis dos Judiciários federal e estaduais rotineiramente determinam a constitucionalidade de legislações federal e provinciais. A Reforma Constitucional argentina de 1994 agora explicitamente autoriza o controle judicial em casos de amparo ${ }^{\text {to }}$.

Como nos Estados Unidos, de cuja boa parte da Constituição foi emprestada, a Argentina é um sistema federal com um sistema desconcentrado de controle judicial. Como nos Estados Unidos, os últimos árbitros do significaldo das leis e Constituições provinciais são as suas respectivas Supremas Cortes. Em virtude de ser um país de sistema de direito civil (civil law), entretanto, a Argentina não opera com o princípio do stare decisis. Consequientemente, determinações de constitucionalidade pelos tribunais argentinos tecnicamente têm apenas efeitos inter partes ${ }^{i 7}$. Não obstante, a Argentina tem um conceito de precedente se bem que não vinculante. As decisões da Suprema Corte, particularmente se reiteradas, são quase invariavelmente seguidas pelos tribunais inferiores. Isto significa que as leis declaradas inconstitucionais pela Suprema Corte permanecem em vigor mas são tratadils como imponiveis ${ }^{48}$.

Paradoxicalmente. durante o último século a Suprema Corte argentina considerou decisões da Suprema Corte dos Estados Unidos como precedentes vinculantes que tinham de ser seguidos até mesmo se estivessem em conflito com as decisóes dos próprios tribunais argentinos ${ }^{49}$. O artigo 45 da efêmera Constituição peronista de 1949, que foi revogada em 1957, estabeleceu que as interpretaçôes constitucionais da Suprema Corte em decisões de recursos extraordinários (writs of error) oriundos dos tribunais inferiores vinculassem os tribunais federais e provinciais.

A Constituição de 1996 da Cidade de Buenos Aires combinal o controle judicial desconcentrado com uma curiosa forma de controle concentrado. O artigo $113 \$ 2$ confere competência originária e exclusiva ao Superior Tribunal de Justiça para conhecer ações diretas de inconstitucionalidade. Uma norma declarada inconstitucional nessas açōes diretas é ab-rogalda, a não ser que seja uma lei, em cujo caso o Legislativo pode mantê-la em vigor se a ratificar por votos de dois terços dentre os três meses da declaração judicial de inconstitucionalidade. A ratificação legislativa não muda o resultado do caso concreto nem impede outros tribunais de declarar a

46 42. O artigo 3 da Lei de Orģanização da Justiça Nacionall. Lei 27 de 13 de out. de 1862 , previu explicitamente que em casos sob decisão, os tribunais deveriam abster-se de aplicar qualquer dispositivo dos outros poderes que contrariassem a Constituição. O article 43. um novo preceito inserido na Constituição da Argentina pela reforma parcial da Lei 24.309 de 1994 , especificamente prevê que em catsos de amparo os tribunais argentinos "devem declarar a inconstitucionalidade da norma em que se funde o atto ou omissão lesiva".

47 Juan Carlos Hitters, La Jurisdicción Constiucional en Argentina in La Jurisdicción Constitucional en Iberoamerica 283. 295 (Domingo García Belaunde \& Francisco Fernández Segado coords. Madrid: Dykinson. S.L. 1997): Alejandro M. Garro, Eficacia y Autoridad del Precedente Constitacional en América Latina: Las Lecciones del Derecho Comparado, 20 UNIV. MIAMI INTERAM. LAW REV. 473. 482483 (1989).

48 Garro, $i d$ at 484-485; Hitters, id. at 295.

49 Jonathan M. Miller. The Authority of a Foreign Talisman: A Study of U.S. Constitucional Practice as Authority in Nincteenth Century Argentina and the Argentine Elite's Leap of Faith, 46 AM. U. L REV. 1483, 1559-1560(1997). 
lei inconstitucional em subseqüentes litígios. Além disso as Constituições de várias províncias argentinas prevêem ações diretas de inconstitucionalidade perante seus Superiores Tribunais de Justiça, cujas decisões declaratórias de inconstitucionalidade de legislações provinciais ou municipais devem resultar em abrogações das normas ou constituir precedentes vinculantes ${ }^{50}$.

\section{Os Efeitos de uma Declaraçăo de Inconstitucionalidade no Equador}

O Equador tem uma peculiar forma híbrida de controle judicial. A Constituição de 1945 criou um Tribunal de Garantias Constitucionais, que não era parte do Judiciário comum. Uma das funções do Tribunal era arbitrar disputas envolvendo vetos de projetos legislativos com fundamentos constitucionais. Se o Presidente vetasse um projeto sob fundamentos constitucionais e o Congresso concordasse, era o seu fim. Se, entretanto, o Congresso discordasse do Presidente, o projeto era enviado ao Tribunal para uma opinião sua constitucionalidade em abstrato. A decisão do Tribunal era vinculante para os outros poderes (art. 41.). O Tribunal também tinha o poder de suspender, tanto total como parcialmente, qualquer lei que julgasse inconstitucional ou qualquer norma que considerasse ilegal a pedido de um juiz ou tribunal de última instância. Mas a decisão do Tribunal não era final. Este tinha que depois apresentar a matéria ao Congresso, que a final determinava se de fato a norma questionada era inconstitucional ou ilegal (art. 160).

Com a adoção da Constituição de 1993, a Turma Constitucional da Suprema Corte tornou-se o último árbitro das questões constitucionais. O Tribunal de Garantias Constitucionais continuou a ter competência para determinar a constitucionalidade de leis e outras normas. Suas decisões determinando que uma lei era inconstitucional, entretanto, não eram finais; o Tribunal podia apenas suspender a eficácia de uma lei. A questão constitucional então tinha que ser resubmetida perante a Turma Constitucional da Suprema Corte para determinação final de constitucionalidade (art. 146). A resolução da Turma Constitucional era definitiva com efeitos gerais (art. 141).

Este sistema foi modificado pela corrente Constituição de 1998, que criou um sistema concentrado de controle abstrato em um Tribunal Constitucional que não é de novo parte do Judiciário. Este Tribunal é composto por nove Vogais (Vocales), eleitos para um mandato renovável de quatro anos pela maioria do Congresso ${ }^{51}$. O

50 E.g., o art. 141 \& I da Const. da Província de La Rioja (1998) dá ao Tribunal de Justice exclusiva jurisdição para conhecer ações diretas de inconstitucionalidade, e o art. 143 faz com que as interpretações do Tribunal de ambas Constituições e outras normas vinculem os juízos inferiores: o art. 9 da Const. da Província do Chaco (1994) prevê uma caducidade de todas as leis e outras normas declaradas inconstitucionais pelo Tribunal de Justiça, enquanto o art. $163 \$$ I (a) dá ao Tribunal de Justiça exclusiva jurisdição para conhecer ações diretas de inconstitucionalidade.

51 Dois são selecionados de uma lista de candidatos indicados pelo Presidente da República, dois são indicados pela Suprema Corte de fora de seus membros, dois indicados pelo Congresso dentre não legisladores, um indicado pelos prefeitos, um indicado pelas centrais de trabalhadores e pelas 
Tribunal tem o poder de resolver controvérsias em abstrato sobre constitucionalidade em seis tipos de casos: (1) demandas de inconstitucionalidade, de fundo ou de forma, sobre qualquer lei orgânica ou ordinária, decretos-lei, decretos, regulamentos, e ordenações; (2) demandas de inconstitucionalidade de qualquer ato administrativo; (3) recursos de denegações de hábeas corpus, hábeas data, e amparo, além de apelações previstos na lei de Amparo; (4) reconsideração de vetos presidenciais baseados em objeções constitucionais; (5) pedidos do Presidente da República para decidir se tratados e convenções são constitucionais, antes deles serem aprovados pelo Congresso; e (6) resoluções sobre a, certeza de declarações de inconstitucionalidade pronunciados pelas turmas da Supreme Corte ou demais tribunais de última instância ${ }^{52}$. As partes legítimas para demandar a, inconstitucionalidade de legislação são o Presidente da República, a maioria do Congresso, a Suprema Corte via previa resolução de pleno, mil cidadãos, ou qualquer pessoa cujo pedido o Defensor do Povo (Defensor del Pueblo) entenda como bem fundamentado. ${ }^{53}$ Salvo o Presidente, as mesmas pessoas, além dos Conselhos Provinciais e Municipais, tem legitimidade para demandar a inconstitucionalidade de actos administrativos ${ }^{54}$. A reconsideração do veto pode ser pedido somente por resolução da maioria do Congresso ou do plenário das Comissões Legislativas.

As decisões do Tribunal, que são publicadas no Diário Oficial, são definitivas e tem efeitos erga omnes. O Tribunal pode declarar uma lei ou outro ato normativo parcialmente ou totalmente inconstitucional, deixando sem efeitos o que foi. declarado inconstitucional. Normalmente. suas decisões não têm efeitos retroativos (art. 278). Mas o efeito da declaração de inconstitucionalidade do ato administrativo é a revogação (art. 276, 2), que necessariamente implica um efeito retroativo. ${ }^{55}$

O Equador também tem um sistema desconcentrado de controle judicial. Todos os tribunais e juízes podem declarar qualquer norma legal inaplicável por causa de seu conflito com a Constituição ou convenções e tratados internacionais. Declarações de inconstitucionalidade pelos juízos ordinários podem ser feitas ex officio, ou a requerimento da parte. Tais declarações têm apenas efeitos inter partes, mas os juizes tem a obrigação de encaminhá-las ao Tribunal Constitucional para que possa decidir a matéria com efeitos erga omnes (art. 274).

Em comparação e em tensão com essas formas de controle judicial está o artigo 284 da Constituição, que confere ao Congresso o poder de interpretar a Constituição de uma maneira que é genericamente obrigatória. Esta decretação legislativa de interpretação constitucional exige a aprovação de dois terços dos membros do Congresso ${ }^{56}$.

organizações indígenas e camponesas de caráter nacional, e um pelas Câmaras de Produção (art. 275).

52 Const. de Ecuador, arts. 276 e 277: Lei de Control Constitucional de 26 de junho 1997, art. 12.

53 Lei de Control Constitucional, art. 18.

54 Id.. art. 23.

55 Jaime Pozo Chamorro. La declaratoria de inconstiucionalidade de actos administrativos (REV. JUDICIAL online http://dlh.lahora.com.ec/paginas/judicial/PAGINAS/D.Consti.... 


\section{Os Efeitos de uma Declaração de Inconstitucionalidade na Colômbia}

A Colômbia é um outro exemplo de sistema híbrido de controle judicial. A Constituição de 1886 produziu um sistema desconcentrado de controle judicial em cujas questões constitucionais poderiam ser suscitadas nas lides ordinárias. Decisões em questões constitucionais em tais processos tinham efeitos apenas inter partes. Além disso, qualquer cidadão podia ajuizar uma ação popular diretamente perante a Suprema Corte para questionar a constitucionalidade de qualquer lei ou decreto. Decisões nesses processos abstratos tinham efeitos erga omnes. Finalmente, a Suprema Corte tinha o poder de determinar definitivamente se qualquer projeto de lei vetado pelo Presidente sob questões constitucionais podia ser promulgado. Essas decisões também tinham efeitos erga omnes.

A corrente Constituição de 1991 criou uma Corte Constitucional que é parte do Judiciário. Seus nove membros são escolhidos pelo Senado para um mandato não renovável de oito anos de candidatos indicados pelo Presidente da República, pela Suprema Corte e pelo Conselho de Estado. A ação popular, agora chamada uma ação direta de inconstitucionalidade, pode ser proposta por qualquer cidadão diretamente perante a Corte Constitucional. que tem o poder de declarar inconstitucional qualquer proposta de emenda constitucional, referendo, plebiscito, lei, ou decreto com força de lei ${ }^{57}$. O Procurador-Geral deve intervir em todas as ações diretas de inconstitucionalidade, enquanto qualquer cidadão pode intervir como autor ou defensor de qualquer providência cuja constitucionalidade esteja sendo submetida à Corte Constitucional. As decisões da Corte em ações diretas de inconstitucionalidade têm o efeito de "absoluta res judicata", que significa "que nenhuma autoridade pode reproduzir a matéria essencial do ato legal declarado inconstitucional por razões de matéria". Entretanto, a Corte Constitucional pode também declarar leis inconstitucionais com efeitos de relativa res judicata, que significa que a Corte expressamente limita os efeitos de sua decisão a certos artigos ou seções da questionada lei ${ }^{58}$.

A Corte Constitucional também tem o poder de controle judicial cautelar. Aprovação, emenda ou revogação de leis especiais (leyes estatutarias) com relação a direitos humanos fundamentais, Administração da Justiça, Partidos Políticos, participação dos cidadãos e estados de exceção têm de passar por anteriores aprovações da Corte Constitucional. Semelhantemente, a Corte deve decidir sobre projetos de lei que o Governo impugna como inconstitucionais, e também sobre a imponibilidade

56 Propostas de lei de interpretação da Constituiçĩo podem ser apresentadas por vinte por cento dos membros do Congresso ou por um bloco legislativo (um partido político ou grupo com pelo menos dez por cento dos inembros do Congresso), pela Suprema Corte, pelo Tribunal Constitucional, ou por um por cento dos eleitores registrados (art. 281).

57 Col. Const. de 1991. art 241. Os referendo. plebiscitos, e emendas à Constituição somente podem ser declarados inconstitucionais com respeito à forma, enquanto as leis e decretos-leis podem ser declarados inconstitucionais com relação à forma e matéria.

58 Eduardo Cifuentez Muñoz. La Jurisdición Constitucional en Colombia, in La Jurisdicción Constitucional en lberoamerica 469.476 (Domingo García Belaunde \& Francisco Fernández. Segado coords. 1997). 
de tratados internacionais e de suas respectivas leis de aprovação [art. 241 (8) e $(10)]$.

Além disso, a Constituição de 1991 criou a ação de tutela, um processo preferencial e sumário para proteção imediata de direitos constitucionais individuais quando ameaçados ou violados por um ato ou omissão de autoridade pública ou individual. A ação de tutela pode ser proposta em qualquer tribunal em um caso concreto, mas a decisão pode a final ser recorrida à Corte Constitucional, que tem o poder de revisar recursos em tais ações de decisões tomadas pelos outros tribunais, incluindo a Suprema Corte e o Conselho de Estado ${ }^{54}$. A decisão em uma ação de tutela tem apenas efeitos inter partes. Por conseguinte, a Colômbia combina os modelos concentrado e desconcentrado de controle judicial.

\section{Os Efeitos de uma Declaração de Inconstitucionalidade no Brasil}

O Brasil tem uma das mais complexas formas híbridas de controle judicial. A Constituição atual prevê duas formas diversas de controle judicial. Uma é incidental. ou difusa de controle judicial perante qualquer juízo estadual ou federal. A segunda é de controle judicial abstrato perante o Supremo Tribunal Federal (STF), e, em certos casos, perante Tribunais de Justiça ${ }^{60}$.

\subsection{Controle Incidental}

Qualquer juízo estadual ou federal pode determinar a constitucionalidade de qualquer lei ou decreto incidentalmente ao decidir um caso concreto. A matéria constitucional deve ser suscitada por uma parte (incluindo uma terceira parte), pelo Ministério Público, ou até mesmo pelo próprio tribunal ex officio ${ }^{61}$ Embora o artigo 97 da Constituição permita aos tribunais que declarem uma lei inconstitucional apenas pela maioria absoluta de seus membros ${ }^{62}$, o STF já sustentou que um juiz

59 V. Jorge Arena Salazar, La Tutela Una Acción Humanitaria 189-192 (Santafe de Bogotá: Ediciones Doctrina y Ley 2d. ed. 1993).

60 O Art. $125 \$ 2^{\circ}$ da Constituição Federal prevê: "Cabe aos Estados a instituição de representação de inconstitucionalidade de leis ou atos normativos estaduais ou municipais em face da Constituiçĩo Estadual, vedada a atribuição da legitimação para agir a um único órgão".

Os Tribunais de Justiça estaduais ganharam competência para conhecer ações diretas questionadoras da constitucionalidade de leis estaduais ou municipais violadoras de suas respectivas Constituiçōes estaduais. Para uma exploração do controle direto de constitucionalidade nos Tribunais de Justiça, v. Clémerson Merlin Clève, A Fiscalização Abstrata da Constitucionalidadade no Direito Constitucional Brasileiro 391-406 (São Paulo: RT, 2d ed. 1999).

6l Id. p. 98. Comumente. a questão constitucional é suscitada por meio de exceção ou de defesa. e a constitucionalidade da lei ou decreto violador não é atacada diretamente; mais exatamente o ataque é dirigido ao ato ou conduta baseado na lei violadora ou decreto. $1 d$. pp. 91-92.

62 Quando a inconstitucionalidade de lei ou ato normativo está argüida, o relator submeterá a questão à turma ou câmara. Se a contenção de inconstitucionalidade for rejeitada, prosseguirá o julgamento. Se for aceito. a questão tem que ser submetida ao tribunal pleno. Mas se houver um 
singular também tem o poder de declarar uma lei inconstitucional ${ }^{63}$. Uma decisão incidental de inconstitucionalidade somente tem efeitos inter partes. O juízo simplesmente recusa-se a aplicar a lei violadora ou decreto ao caso perante ele, e essa decisão é vinculante apenas para os litigantes.

O Brasil é, no entanto, um dos poucos países de sistema de direito civil (civil law) que permitem ações coletivas (class actions) se bem que em contextos limitados, principalmente em lides relativas ao meio ambiente e relações de consumo ${ }^{64}$. Além disso, a Constituição de 1988 criou o mandado de segurança coletivo ${ }^{65}$. Embora a Súmula 266 do STF estabeleça que o mandado de segurança não possa ser utilizado para questionar a constitucionalidade de uma lei em tese, a jurisprudência, com forte suporte doutrinário, permite seu uso contra uma lei de efeitos concretos ${ }^{66}$. Por conseguinte, o mandado de segurança coletivo e a ação coletiva podem dar ampla aplicação do controle incidental a grandes grupos. As decisões judiciais brasileiras, com exceção de quatro tipos de ações diretas de inconstitucionalidade discutidos adiante, não têm força de precedentes vinculantes ${ }^{67}$. Isto deve logo mudar. A proposta de Emenda constitucional para a Reforma do Judiciário ( $N^{\circ}$ 96-C de 1992), que está pendente de aprovação final, adicionará um novo artigo 103A autorizando o STF, tanto por ele próprio quanto a pedido, aprovar súmulas depois de reiteradas decisôes sobre uma questão jurídica que vinculará erga omnes. A emenda proposta também fará existir súmulas do STF vinculantes para o restante do Judiciário após a confirmação do voto de dois terços e publicação no Diário Oficial.

pronunciamento do tribunal pleno ou do plenário do STF sobre a constitucionalidade ou inconstitucionalidade da lei questionada, a turma ou câmara não tem que submeter it questão ao tribunal pleno. Nesse caso, pode submeter a questão ao tribunal pleno ou aplicar a decisão prévia do plenário do STF ou do próprio tribunal. Código de Processo Civil. arts. 480 e 481 , com a reforma pela Lei 9.756 de 1998 .

63 RE 89.553, 97 R.T.J. 1191, 554 R.T. 253, Relitor: Min. Ratael Mayer (STF 1981).

64 V. Antonio Guidi, Class Actions in Brazil, 51 AM. J. COMP. L. - (2003) (no prelo).

65 61. O mandado de segurança coletivo pode ser proposto por qualquer partido político com representação no Congresso Nacional, assim como por qualquer organização sindical, entidade de classe ou associação legalmente constituída e em funcionamento há pelo menos um ano, em defesa dos interesses de seus membros ou associados. Const. de 1988, art. 5 (LXX).

66 V. Hely Lopes Meirelles, Mandado de Segurança. Ação Popular. Mandado de Injunção e Ação Declaratória de Constitucionalidade 38-39 (Sĩo Paulo: Revista dos Tribunais, 22d ed. atual. por Arnoldo Wald \& Gilmar Ferreira Mendes, 2000).

67 Desde 1963, o Brasil tem uma forma de precedente chamado Súmula, que consiste em regras de direito numeradas escritas em estilo gótico. Essas regras sintetizam a jurisprudência do Tribunal na solução de matérias específicas. De acordo com o artigo 479 do Código de Processo Civil, os julgamentos proferidos pelo voto da maioria absoluta dos membros que integram o tribunal, "será objeto de súmula e constituirá precedente na uniformização da jurisprudência". Uma vez tenha a regra sido insculpida em Súmula, qualquer argumento contrário sobre ela será sumariamente rejeitado salvo se o tribunal estiver preparado para mudar a súmula. Não obstante, as súmulas não são realmente precedentes vinculantes no sentido americano do termo. V. Lenio Luiz Streck, Súmulas no Direito Brasileiro: Eficácia. Poder e Função (Porto Alegre: Livraria do Advogado, 2d ed. 1998). 
Um decreto presidencial atual vai mais além da emenda constitucional proposta com respeito às agências da administração pública federa ${ }^{68}$. $\mathrm{O}$ artigo $\mathrm{l}$ deste decreto determina que todos os órgãos da administração pública federal, direta e indireta, obedeçam às decisões finais do STF que, de forma inequívoca e definitiva, fixem interpretação do texto da Constituição. Uma vez firmada a jurisprudência do STF com referência à constitucionalidade de uma lei ou ato administrativo, o Advogado Geral da União deve publicar uma súmula sobre a matéria no Diário Oficial ${ }^{69}$. Os Procuradores Gerais das agências federais críticas, como a Fazenda Nacional e Previdência Social, também são instruídos a deixar de invocar leis e decretos cujas inconstitucionalidades tenham sido definitivamente determinadas pelo $\mathrm{STF}^{70}$.

Desde 1934, as Constituições brasileiras têm contido um mecanismo incomum de conversão de decisões de inconstitucionalidade com efeitos inter partes em decisões com efeitos erga omnes. Quando o STF definitivamente determina que uma lei federal, estadual ou municipal é inconstitucional" . o Presidente do Tribunal remete uma cópia da decisão ao Senado, que tem o poder de editar uma resolução suspendendo, no todo ou em parte, a norma legal inconstitucional ${ }^{72}$. Uma vez que isto é análogo a uma revogação legislativa, teoricamente a resolução do Senado suspendendo a lei inconstitucional deveria ter apenas efeitos prospectivos. Porém a doutrina brasileira é dividida neste ponto, alguns considerando a resolução do Senado com operação de efeitos retroativos e outros prospectivos ${ }^{73}$. A Constituição não exige, entretanto, que Senado suspenda a norma violadora, e o Senado tem ocasionalmente declinado a fazê-lo ${ }^{74}$. O Senado tem discricionariedade em se e quando

68 Decreto $n^{\circ} 2.346$ de 10 de outubro de 1997.

69 id., art. 2.

$70 \quad l d .$, arts. 4-6.

71 O STF reunido em turmas, e suas decisões são algumas vezes inconsistentes. O termo "definitivo" implica uma série de decisões, mas não um particular número de decisões é exigido. Normalmente o Presidente do STF não enviará um parecer ao Senado até depois da jurisprudência ter sido firmada, o que significa que o STF devidiu vários calsos concluindo que uma norma particular é inconstitucional. V. Ada Pellegrini Grinover, Controle da Constitucionalidade, 90 REV. PROCESSO 11, 12 (Apr.Je. 1998).

72 Const. de 1988, art. 52(X). Este preceito originado da Constituição de 1934, art. 9! (IV).

73 V. Lenio Luiz Streck, Jurisdição Constitucional e Hermenêutica 376-378 (Livraria do Advogado: Porto Alegre 2002). V. tb. Pauto Napoleño Nogueira da Silva, O Controle da Constincionalidade é o Senado 138 (Rio: Forense, $2 \mathrm{~d}$ ed. 2000).

74 Por exemplo, o Senado recusou-se a suspender certos artigos de uma lei federal impositora de contribuições para o Fundo de Investimento Social (FINSOCIAL) por duas razões: (1) o STF declarou a lei inconstitucional pelo voto de seis a cinco dos onze ministros, e (2) dando à decisão efeitos erga onnes haveria sérias repercussōes fiscais para a Fazenda Nacional. RE 150.764-1, discutido em Clève supra nota 56, at 276, nota 10 . O Senado algumas vezes espera um longo tempo antes de adotar qualquer ação com respeito às decisões do STF que the são enviadas. De acordo com um censo feito em 28 de outubro de 1997, havia 69 decisões aguardando ações do Senado. Algumas eram recentes, mas outras tinham sido enviadas pelo STF nas décadas de 70 e 80 . Streck, supra nota 69, p. 379. 
suspender uma norma definitivamente declarada inconstitucional pelo STF $^{75}$. Uma vez suspensa uma lei ou decreto, no entanto, o Senado não pode ressuscitá-la, nem no todo nem em parte ${ }^{76}$.

A Constituição de 1988 é programática, exigindo a edição de mais de duzentas leis para implementar direitos criados por ela. Para evitar denegações desses direitos se tais legislações não forem editadas, a Constituição criou um novo remédio chamado mandado de injunção. O art. 5 (LXXI) prevê que "conceder-se-á mandado de injunção sempre que a falta de norma regulamentadora torne inviável o exercício dos direitos e liberdades constitucionais e das prerrogativas inerentes à nacionalidade, à soberania e à cidadania". Este preceito, que ainda tinha de ser regulamentado, criou uma considerável confusão. Ainda que o STF tenha sustentado que ele é auto-aplicável, utilizando-se o procedimento do mandado de segurança, o mandado de injunção não tem sido um remédio constitucional eficaz. Exceto em raros exemplos, o STF não tem sido apto a prover um remédio eficaz se o Congresso falha em editar a legislação necessária para implementar uma garantia constitucional ${ }^{77}$.

\subsection{Controle Concentrado}

Quatro tipos de ações diretas podem ser propostas exclusivamente perante o Supremo Tribunal Federal para determinar a constitucionalidade de leis ou decretos em abstrato: (1) a ação direta de inconstitucionalidade. (2) a ação declaratória de constitucionalidade, (3) a ação de descumprimento de preceito fundamental e (4) a ação de inconstitucionalidade por omissão. As decisões do STF em todos estes tipos de ações têm efeitos erga omnes. Normalmente, se uma lei ou decreto é declarado inconstitucional em uma ação direta de inconstitucionalidade ou em uma ação de descumprimento de preceito fundamental, a decisão tem efeitos retroativos. No entanto, em casos excepcionais, o STF, por maioria de dois terços, tem o poder de manipular os efeitos de suas decisões então aplicam apenas prospectivos ou somente para certas situações ${ }^{78}$

\subsubsection{A Ação Direta de Inconstitucionalidade}

Em uma ação direta o STF decide a constitucionalidade de uma lei ou decreto questionado em abstrato. Um mínimo de oito Ministros é exigido para votar em ações diretas, e pelo menos seis votos são necessários para declarar uma lei ou decreto inconstitucional ${ }^{79}$. Tecnicamente, não há partes conflitantes. Em Constitui-

75 Clève, supra nota 56, p. 121.

76 Engenharia Souza e Barker Ltda. et al. v. Senado Federal, RMS n 16.512, 38 R.T.J. 5 (STF 1966).

77 Luís Roberto Barroso, Mandado de injunção: o que foi sem nunca ter sido. Uma proposta de reformulaçāo, in Luís Roberto Barroso, Temas de Direito Constitucional 189198. Tomo I (Rio:

Renovar 2001.

78 Lei $\mathrm{n}^{\circ} 9.882$ de 1999 , art. 11.

79 Lei $n^{\circ} 9.868$ de 1011.1999 , art. 23; Regimento Interno do STF, arts. 143 e 173. 
ções anteriores, somente o Procurador-Geral da República tinha legitimidade para propor tal ação, então chamada representação ${ }^{80}$. A Constituição de 1988 significativamente expandiu a legitimidade de propositura da ação direta para questionar qualquer lei federal ou estadual ou atos normativos incluindo (além do ProcuradorGeral da República) o Presidente da República, as Mesas de cada Casa do Congresso Nacional ou de qualquer Assembléia Legislativa estadual ou do Distrito Federal, qualquer Governador, o Conselho Federal da Ordem dos Advogados do Brasil, qualquer partido político com representação no Congresso Federal. e qualquer confederação sindical ou entidade de classe nacional [art. 103, I ao VIII]. Terceiros não podem intervir nesses processos ${ }^{81}$. O relator deve sumariamente rejeitar ações frívolas $^{82}$. O Procurador-Geral deve emitir parecer. e os órgãos governamentais dos quais emanaram os atos impugnados serão normalmente solicitados parra prestar informações mas não para defender a norma ou seus próprios interesses ${ }^{\gamma 3}$. O Advogado Geral da União tem a responsabilidade de defender a questionada lei ou decreto (art. $103 \S 3$ ).

Para evilar ser inundado com ações diretas de inconstitucionalidade, o STF desenvolveu a doutrina da "pertinência temática", denegando legitimidade a algumas classes constitucionalmente designadas de reclamantes por insistir em um elo objetivo entre o dever institucional do proponente e a norma questionada ${ }^{84}$. Por outro lado, a doutrina da pertinência temática não é aplicada às ações diretas propostas pelo Procurador-Geral da República, pelo Conselho Federal da Ordem dos Advogados do Brasil, ou Partidos Políticos, todos os quais são julgados possuidores de um interesse geral na constitucionalidade ${ }^{85}$.

O STF toma uma visão restrita sobre seus poderes de interpretação em ações diretas de inconstitucionalidade, caracterizando seu papel como simples "legislador

80 A representação foi instituída pela Constituição de 1934. Sob Constituições anteriores. o Presidente podia dispensar o Procurador-Geral à vontade, algo que já não o pode fazer diante da presente Constituição. Além disso, os mais altos tribunais estaduais. chamados Tribunais de Justiça, podem conhecer ações chamadas representações, que são ações diretas de inconstitucionalidade que poderia levar a uma intervenção federal nos estados, ou estadual nos municípios. Id. arts. 34 (VII), 35 (IV), e 36 (III).

81 Lei $n^{\circ} 9.868$ de 10. 11. 1999, art. 7.

82 Lei $n^{\circ} 9.868$ de 10111999 , art 4. Esta decisão é recorrivel. ao plenário do STF.

82 Sydney Sanchez, Aspectos Processuais do Controle de Constitucionulidade, in 2 Estudos em Homenagem a Geraldo Alaliba 602, 609 (Celso Antonio Bandeira de Mello ed. 1997).

8. Por conseguinte. o STF denegou legitimidade à mesil de uma Assembléia Legislativa para impugnar a constitucionalidade de uma lei federal e resoluções do Conselho Monetário Nacional que tratavam de crédito rural, assim como a uma confederação de organizações de negócios questionando a constitucionalidade de uma lei impositiva às entidades legais de usar advogados para registrar seus estatutos ou mudá-los nesse particular.

85 Carlos Antonio de Almeida Melo, Algumas Questōes Objetivas sobre Ação Direta de Inconstitucionalidade, 36 REV. INFORM. LEGIS. $111,117-118$ (Abr./Je. 1999). Para uma síntese da jurisprudência do STF sobre a legitimidade nas ações diretas, v. Luís Roberto Barroso, Constituição da República Federativa do Brasil 238-38 (Sāo Paulo: Saraiva 1998). 
negativo" ${ }^{86}$. Por outro lado, o STF adotou dos Estados Unidos e do Direito Constitucional alemão o expediente de declarar uma lei constitucional apenas se interpretada de uma forma específica ${ }^{87}$. Suas decisões sobre constitucionalidade, inconstitucionalidade, e interpretação constitucional são vinculantes para todo o Judiciário federal e estadual, e também para os governos federal, estaduais e municipais ${ }^{88}$. Portanto, o STF não envia uma decisão declaratória de lei inconstitucional em ação direta ao Senado para suspensão. Tecnicamente, entretanto, a decisão do Supremo de que uma norma é inconstitucional não revoga a norma violadora; a decisão simplesmente a suspende indefinidamente ${ }^{\delta y}$.

\subsubsection{A Ação Declaratória de Constitucionalidade}

A Emenda constitucional $n^{\circ} 3$ de 1993 atribuiu competência originária e exclusiva ao STF para conhecer "ação decłaratória de lei ou ato normativo federal". À primeira vista, a ação declaratória aparece redundante com a ação direta de inconstitucionalidade. Porém há importantes diferenças. Legitimados a propor a ação declaratória de constitucionalidade estão apenas três tipos de agentes federais: (1) o Presidente da República, (2) as Mesas da Câmara ou do Senado, ou (3) o Procurador-Geral da República. Além disso, a ação declaratória somente pode ser proposta com relação à legislação federal.

O objetivo básico da ação declaratória de constitucionalidade "é evitar a demora $e$ as contradições em relação a questões constitucionais de alta relevância, que se não forem resolvidas rapidamente, podem ensejar um verdadeiro caos jurídico, prejudicando a economia nacional e o próprio desenvolvimento do País" "\%o . A ação declaratória provê o Governo Federal com um importante aparelho processual para conter a "indústria de liminares" que tribunais inferiores expediram para bloquear leilões de privatizações, para concessões de aumentos de vencimentos a servidores

86 Procurador-Geral da República v. Presidente da República e Congresso Nacional, ADIn n 896 , 159 R.T.J. 111, 121 (STF pleno 1993) (Voto do Rel. Moreira Alves).

87 Governador do Estado do Amazonas v. Governador do Estado do Amazonas, Assembléia Legislativa do Estado do Amazonas, ADIn no 491, 137 RTJ. 90, 99-100 (STF pleno 1991) (Voto do Rel. Moreira Alves): Governador do Estado do Espírito Santo v. Assembléia Legislativa do Estado do Espírito Santo, ADIn n 1344, 205 R.D.A. 196, 200-201 (STF pleno 1995) (Voto do Rel. Moreira Alves). Nos Estados Unidos, esta técnica é comumente chamada de "interpretação para salvar a lei de dúvidas constitucionais". No Brasil, é chamada de "interpretação em conformidade com a Constituição". V. Sỵdney Sunchez. nota supra 79, p. 613.

88 Lei $n^{\circ} 9.868$ de 10.11.1999, art. 28, paraigrafo único. O texto constitucional é um tanto quanto limitado, fazendo com que as decisōes detinitivas do STF de mérito em açōes declaratórias de constitucionalidade de apenas leis federais ou atos normativos vinculem erga omnes. Const. do Brasil, art. $102 \$ 2$.

89 Carlos Antonio de Almeida Melo, nota supra 81, p. 116.

90 Arnoldo Wald, Alguns Aspectos da Açāo Declaratória de Constitucionalidade, 76 REV. PROCESSO 7, 19 (Oct-Dez. 1994). 
públicos, ou para declarar tributos inconstitucionais. Como uma ação originária no STF, cuja decisão é vinculante erga omnes, a ação declaratória evita qualquer necessidade para o STF de baixar um caso para os tribunais inferiores.

\subsubsection{O Descumprimento de Preceito Fundamental}

O artigo $102 \$ 1$ da Constituição de 1988 cria uma ação direta perante o STF por "descumprimento de preceito fundamental". Como finalmente regulamentado pela Lei 9.882 de 03.12.1999, o mesmo grupo restrito de agentes e organizações legitimados a propor a ação direta de inconstitucionalidade também pode propor uma alegação de descumprimento de preceito fundamental diretamente perante o STF $^{91}$. Este aparelho processual pode ser invocado, entretanto, somente se nenhum outro remédio efetivo para curar o mal existir" ${ }^{42}$. O significado do termo "preceito fundamental" não é inteiramente claro. A doutrina o descreve para incluir muito mais que "princípios fundamentais" previstos nos artigos 1 a 4 da Constituição, estendendo aos direitos individuais e coletivos garantidos no artigo 5 ou talvez a todos aqueles princípios que não podem ser mudados por emenda constitucional, i.e., as chamadas cláusulas pétreas (art. $60 \$ 4)^{9.3}$. A ação pode ser utilizada apenas para questionar atos governamentais. Pelo voto de uma maioria absoluta do STF existe o poder de determinar um remédio provisório suspendendo procedimentos em qualquer caso perante os tribunais inferiores ou suspendendo os efeitos de qualquer decisão judicial a não ser que seja res Judicata ${ }^{44}$. Pelo menos dois terços dos membros do STF devem estar presentes para decidir o mérito, que pode resultar em uma declaração de inconstitucionalidade de qualquer lei ou ato normativo. A determinação de constitucionalidade do STF neste tipo de processo tem efeitos erga omnes $e$ é vinculante para todos os órgãos governamentais ${ }^{45}$. Como a ação declaratória, a de descumprimento de preceito fundamental serve como uma medida para habilitar o STF a conter a "indústria de liminares" trazendo a controvérsia diretamente perante ele.

91 Um preceito permitindo a qualquer um lesado ou ameaçado de lesão de propor essa açūo foi vetado em razão da preocupação com o excessivo número de açōes que disto poderia resultar.

92 Lei $n^{\circ} 9.882$ de 3.12.1999. art 4 \$: ADPF n 17. D.J. 14.02.2003 (Rel. Min. Galvão).

93 V. Olavo Augusto Vianna Alves Furreira \& Rodrigo Picroni Fernandes. A Argüiçāo de Descumprimento de Preceito Fundamental e a manipulação dos efeitos de sua decisão, 363 R. F. 121, 125-126 (Sept.-Oct. 2002).

94 Em casos de extrema urgência, o relator sozinho pode conceder uma medida liminar, remetendo a questão ao pleno do STF. Lei No. 9.882 de 1999, art. 5 \$ 1 .

$95 \mathrm{ld}$. art. $10 \$ 3$. Um argumento foi feito de que é inconstitucional ao Legislador dar efeitos erga omnes às decisões do Supremo Tribunal Federal porque viola o princípio da separação dos poderes e priva os juizes de tribunais inferiores de independência. Ferreira \& Fernandes, nota supra 89, 363 R.F. 132-134. O argumento é difícil de ser tomado seriamente. Foi rejeitado pelo pleno do STF com relação $\dot{a}$ ação declaratória de constitucionalidade na ADC n 1. 157 R.T.J. 371 (1993). 


\subsubsection{A Ação de Inconstitucionalidade por Omissão}

A Constituição confere competência ao STF para conhecer originariamente ações diretas de inconstitucionalidade por omissão quando o Congresso ou agências governamentais falharem na edição de legislação ou regulamentações necessírias para fazer normats constitucionais efetivas. Legitimados para propor esta ação direta são apenas aquelas mesmas pessoas ou enticlades que podem propor a ação direta de inconstitucionalidade. Se uma agência governamental é a responsável, o STF pode expedir uma ordem determinando a adoção das regulamentações necessárias em trinta dias. Se o responsálvel é o Congresso. o Supremo pode expedir uma notificação de que o Parlamento precisa agir para adotar a legislação necessária, mas não tem poder para compelir o Congresso a editar a legislação necessária (art. 103 $\S 2$ ). As considerações sobre a separação de poderes que impediram o mandado de injunção de se tornar um remédio efetivo para omissões legislativas também obstaram a ação direta de inconstitucionalidade por omissĩo de se tornar um remédio efetivo ${ }^{96}$

\section{As Vantagens e Desiantagens dos Efeitos Erga Omnes e Inter Partes}

Existem diversas boas razões políticas para conferir efeitos erga onnes em determinações de inconstitucionalidade pelas Supremas Cortes ou Tribunais Constitucionais. Uma, isso assegura uniformidade de interpretação da Constituição e igual tratamento dos litigantes. Não há razão lógica para a interpretação da Constituição mudar simplesmente porque um caso foi conhecido por um painel diferente de juízes, ou pelos mesmos juízes em um dia distinto. Duas, isso promove eficiência judicial. O fato de que o Supremo Tribunal Federal brasileiro teve que decidir sobre a constitucionalidade de um empréstimo compulsório mais de 10.000 vezes é absur$\mathrm{do}^{97}$. Dando a uma simples interpretação efeitos erga omnes evita um grande número de causas repetitivas. Três. isso promove melhores decisōes e melhores pareceres. Com menos casos a decidir e mais tempo devotados em suas próprias decisões. os tribunais tem mais tempo para deliberar, para pesquisar e para escrever suas próprias decisões. Quatro, decisões erga omnes promovem segurança jurídica. Juizes, advogados, agentes governamentais, e cidadãos comuns têm uma melhor compreensão de quais são seus direitos e deveres se há uma só, autorizada interpretação da Constituição. Cinco, sistemas concentrados de controle judicial que permitem um desafio direto da constitucionalidade de um projeto de lei ou tratado, como Chile, Colômbia e Equador, evitam a necessidade de se conviver com uma norma inconstitucional vigorante por muitos anos. Lides comuns podem levar muitos anos antes de ser conhecidas pelos mais altos tribunais. Se sua decisĩo é vinculante apenas inter partes, uma lei inconstitucional pode ficar em vigor indefinidamente.

96 Streck, nota supra 69, pp. 615, 621

97 Afirmação do Ministro Sepúlveda Pertence, 1 Revista Consulex nº 3, Mar. 1997, p. 10. 
Por outro lado, há sérias desvantagens em dar às decisões constitucionais das Supremas Cortes ou Tribunais Constitucionais efeitos erga omnes era processos abstratos. Uma, isso grandemente aumenta a ameaça à independência judicial de autoridades políticas infelizes por fazer decisões judiciais de inconstitucionalidade muito mais pomposas. A declaração judicial de que uma lei ou decreto é inconstitucional não sem frequiencia enfurece Legislativos e Executivos. A despeito das garantias constitucionais de ocupação do cargo. frequientemente tribunais latino-americanos, como maletas, têm sido empacotadas ou desempacotadas por Presidentes ou Legisladores infelizes com decisões judiciais"s. Duas, ameaças à independência judicial são exacerbadas por sistemas de controle judicial que não dão aos tribunais qualquer discrição para recusar o conhecimento de certos tipos de questionamentos constitucionais que provavelmente criarão sérios problemals políticos ou constrangimentos para os tribunais". "Três, quando matérias constitucionais são decididas em abstrato e sem contendas adversárias dos dois lados, a probabilidade de uma decisão judicial errônea é muito maior. O controle judicial incidental desenvolveu uma variedade de doutrinas e técnicas para assegurar que as matérials constitucionais e suas implicações sejam apresentadas claramente. com fatos e fundamentos adequados, pelas partes que são adversárias em um caso concreto. Nos Estados Unidos, casos constitucionais são quase sempre conhecidos primeiramente perante juízes singulares, que são advogados experientes que não se esquivam em decidir questōes políticas importantes. Antes de decidir matérias constitucionais, eles desenvolvem um detalhado relato mostrando como a lei ou decreto afeta os direitos dos reais litigantes. Questões controvertidas podem ser recorridas para uma turma de três juízes em um tribunal de apelação, que podem ser esperados com mais relevância substantiva fora das considerações históricas, legais, e políticas essenciais para determinações de constitucionalidade. Melhores decisões são provavelmente feitas em casos com o benefício de um completo relato e opiniōes bem refletidas pelos tribunais inferiores após considerar os argumentos das partes adversas, assim como do amicus curiae. Os Supremos Tribunais e Tribunais Constitucionais latino-ame-

98 V. Keith S. Rosenn, The Protection of Judicial Independence in Latin America, 19 U. MIA.MI INTER-AM. L. REV 1. 27 (1988). Desde que este artigo foi publicado, houve numerosos outros ataques políticos aos Judiciúrios latino-americanos. Por exemplo, em 1990, a acusaçōes de impeachment foram propostas contra oito membros da Suprema Corte boliviana por declarar inconstitucional um aumento de imposto em cervejas. Em dezembro de 1994, a inteira Suprema Corte mexicana foi aposentada compulsoriamente por emenda constitucional. A Assembléia Constituinté que minutou a Constituição da Venezucla de 1999 também removeu a inteira Suprema Corte, assim como mais de 300 outros juízes. Em maio de 1997, três membros do Tribunal Constitucional do Peru foram sumariamente expulsos pelo Congresso porque tiveram a ousadia de discordar de um terceiro mandato ao Presidente Fujimori. Em janeiro de 2002, o Congresso argentino considerou acusaçōes de impeachment de todos os nove membros da Suprema Corta

99 Nos Estados Unidos. unia seqüencia das leis entre 1891 e 1988. paulatinamente argumentou o poder da Suprema Corte através do writ of certiorari a recusar conhecer qualquer calso que pelo menos quatro Justices não quciram decidir. A Argentina e o México adotaram recentemente análogos instituiçōes processais. V. Maria Angélica Gellí, El "writ of cerriorari" en perspectiva, 1994-B REV.JUR. ARG. LA LEY 880. 
ricanos que têm que decidir matérias constitucionais em abstrato sem o beneficio de opiniões refletidas dos tribunais inferiores e sem os argumentos detalhados das partes adversárias têm com freqüência sérias desvantagens com respeito às perspectivas e qualidades das informações e argumentos. A maior parte dos juízes tem melhor percepção tardia que previdência. É muito mais difícil determinar a constitucionalidade de uma lei em abstrato que num contexto de um caso específico onde o tribunal pode ver como o direito de uma parte realmente foi afetado. Quatro, juízes de civil law são igualmente por treinamento e temperamento mal preparados para desempenhar a delicada função política de controle judicial. O modelo europeu de controle judicial concentrado faz do Tribunal Constitucional parte do processo legislativo. Em muitos países europeus, os membros dos Tribunais Constitucionais são escolhidos para mandatos por Legislativos em um processo altamente politizado. Em muitos países latinoamericanos, entretanto, juízes de carreira com vitaliciedade são esperados a desempenhar o mesmo papel. O resultado é normalmente menos satisfatório. Cinco, errôneas determinações de inconstitucionalidade abstratas são muito mais difíceis de corrigir que as concretas inter partes. Em sistemas difusos, casos com tempo excedente são freqüentemente diferenciados de seus fatos, produzindo muita flexibilidade necessária no sistema. Determinações abstratas não têm fatos a distinguir, e o efeito é normalmente a ab-rogação da lei violadora. O desfazimento de um equívoco é virtualmente impossível salvo se o Legislativo repassar a lei a fim de dar ao tribunal uma segunda mordida na maçã.

$\mathrm{Na}$ década passada. os tribunais latino-americanos se tornaram cada vez mais envolvidos em declarações de importantes peças de legislação inconstitucionais ${ }^{100}$. Como resultado, eles estão se transformando em maiores atores políticos, particularmente quando suas decisões têm efeitos erga omnes. O perigo é que quando o pêndulo político se desloca os tribunais que se tornaram vigorosos impositores das garantias constitucionais podem eles mesmos vir a ser vítimas da política. Como Alexander Hamilton há muito observou. o Judiciário é o Poder mais fraco, não possuindo nem o poder da bolsa nem da espada. Há um perigo real para a independência judicial onde juízes do civil law são forçados a decidir toda questão constitucional submetida a eles em processos abstratos sem partes. Enquanto incrementado o ativismo judicial em defesa de direitos constitucionais é um desenvolvimento bem-vindo, forçar juízes a se balançarem em uma corda sem uma rede de segurança pode resultar por último em uma desastrosa queda para os juízes latinoamericanos.

100 Por exemplo, a Suprema Corte argentina declarou inconstitucional a legislaçĩo que instituiu o corralito em Banco de Galicia y Buenos Aires (Carlos Smith) Y. P.E.N. 2002-A Lal Ley 768 (2002) e pesificação em San Luis, Província de c/Estado Nacional, - La Ley - (Mar. 5. 2003) http://www.diariojudicial.com; O Tribunal Constitucional da Colômbia provocou controvérsia ao sustentar que é inconstitucional a criminalizaçăo de pequenas quantidades de drogas para uso próprio, Sentencia ${ }^{\circ} \mathrm{C} 221 / 94$, Gaceta de la Corte Constitucional: e até a Suprema Corte mexicana recentemente opôs-se ao Executivo declarando inconstitucional, um decreto presidencial permissivo de venda de adicional energia elétrica. Controversia Constitucional 22/2001. decisão de 25 de abril de 2002, D.O., Segunda Sec. 52.108, 3 de junho de 2002. 


\section{O Devido Processo Legal Tributário}

Alberto Nogueira

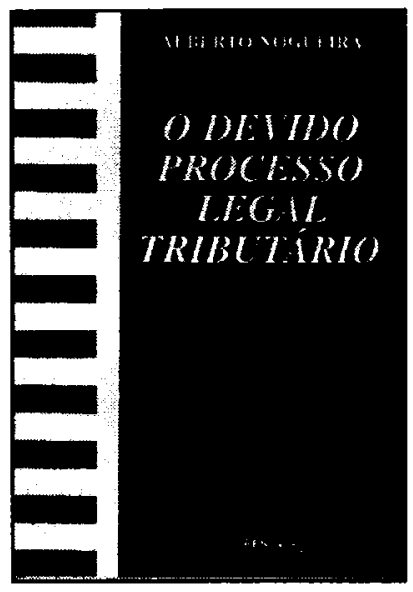

Este livro abrange a relevância da cláusula do devido processo legal no âmbito da tributação. $O$ autor formulou uma fascinante teoria integrativa entre $o$ processo, a organização judiciária e o juiz. $\mathrm{O}$ due process of law é examinado a partir de seu contexto histórico e logo localizado no plano da realidade tributária brasileira. $\mathrm{O}$ autor dedica-se ao exame dos aspectos instrumentais do devido processo legal, ao processo moderno em face da crise da justiça e à organização judiciária entre outros assuntos de relevância no Processo Legal Tributário.

Ref. 0080

Form. 14x21
Brochura

1997
230 págs. $2^{2}$ ed.

\section{O Direito - Introdução e Teoria Geral}

\section{José de Oliveira Ascensão}

O autor é um dos mais eminentes juristas portugueses e que, durante muitos anos, exerceu o magistério no Brasil. Trata-se de um verdadeiro "clássico" na matéria, talvez a mais completa obra lançada no Brasil sobre o tema, e será útil a todos os profissionais do Direito devido à precisão dos conceitos. Por outro lado, vem preencher uma lacuna para os estudantes que não encontrarāo obra similar. A presente edição foi escrita para os brasileiros e se refere ao nosso Direito, que o Professor Ascensão conhece profundamente.

Ref. 0069

Brochura

Form. $16 \times 23$ 1994

546 págs.

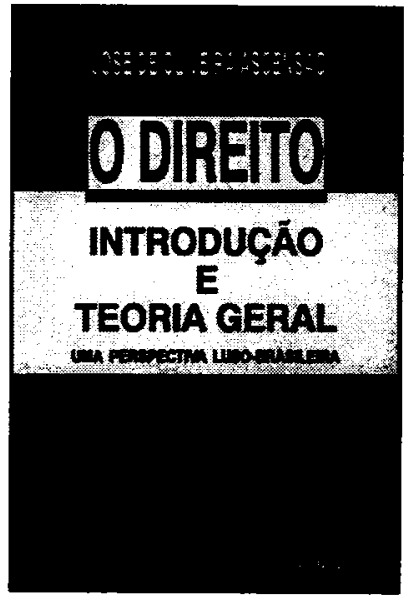

